\title{
A deglacial and Holocene record of climate variability in south-central Alaska from stable oxygen isotopes and plant macrofossils in peat
}

\author{
Miriam C. Jones $^{\mathrm{a}, \mathrm{b}, *}$, Matthew Wooller ${ }^{\mathrm{b}, \mathrm{c}, \mathrm{d}}$, Dorothy M. Peteet ${ }^{\mathrm{e}, \mathrm{f}}$ \\ ${ }^{a}$ U.S. Geological Survey, National Center, Reston, VA 20192, USA \\ ${ }^{\mathrm{b}}$ Water and Environmental Research Center, Institute of Northern Engineering, University of Alaska Fairbanks, Fairbanks, AK 99775, USA \\ ${ }^{\mathrm{c}}$ Alaska Stable Isotope Facility, School of Fisheries and Ocean Sciences, University of Alaska Fairbanks, Fairbanks, AK 99775, USA \\ d Alaska Quaternary Center, University of Alaska Fairbanks, Fairbanks, AK 99775, USA \\ e Goddard Institute for Space Studies, New York, NY 20025, USA \\ ${ }^{\mathrm{f}}$ Lamont Doherty Earth Observatory, Palisades, NY 10964, USA
}

\section{A R T I C L E I N F O}

\section{Article history:}

Received 21 August 2013

Received in revised form

20 December 2013

Accepted 21 December 2013

Available online 21 January 2014

\section{Keywords:}

Holocene

Oxygen isotopes

Peat

Aleutian Low

Carbon

\begin{abstract}
A B S T R A C T
We used stable oxygen isotopes derived from bulk peat $\left(\delta^{18} \mathrm{O}_{\text {Tом }}\right)$, in conjunction with plant macrofossils and previously published carbon accumulation records, in a $\sim 14,500$ cal yr BP peat core (HT Fen) from the Kenai lowlands in south-central Alaska to reconstruct the climate history of the area. We find that patterns are broadly consistent with those from lacustrine records across the region, and agree with the interpretation that major shifts in $\delta^{18} \mathrm{O}_{\text {TOM }}$ values indicate changes in strength and position of the Aleutian Low $(\mathrm{AL})$, a semi-permanent low-pressure cell that delivers winter moisture to the region. We find decreased strength or a more westerly position of the $\mathrm{AL}$ (relatively higher $\delta^{18} \mathrm{O}_{\mathrm{TOM}}$ values) during the Bølling-Allerød, Holocene Thermal Maximum (HTM), and late Holocene, which also correspond to warmer climate regimes. These intervals coincide with greater peat preservation and enhanced carbon (C) accumulation rates at the HT Fen and with peatland expansion across Alaska. The HTM in particular may have experienced greater summer precipitation as a result of an enhanced Pacific subtropical high, a pattern consistent with modern $\delta^{18} \mathrm{O}$ values for summer precipitation. The combined warm summer temperatures and greater summer precipitation helped promote the observed rapid peat accumulation. A strengthened AL (relatively lower $\delta^{18} \mathrm{O}_{\text {TOM }}$ values) is most evident during the Younger Dryas, Neoglaciation, and the Little Ice Age, consistent with lower peat preservation and C accumulation at the HT Fen, suggesting less precipitation reaches the leeward side of the Kenai Mountains during periods of enhanced AL strength. The peatlands on the Kenai Peninsula thrive when the AL is weak and the contribution of summer precipitation is higher, highlighting the importance of precipitation seasonality

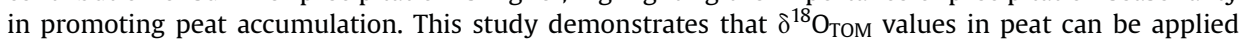
toward understand large-scale shifts in atmospheric circulation over millennial timescales.
\end{abstract}

Published by Elsevier Ltd.

\section{Introduction}

Numerous large-scale climate phenomena have been documented in Alaska during the deglacial and Holocene period. Evidence for a Younger Dryas (YD) cold reversal are well documented from Kodiak Island (Peteet and Mann, 1994) and Glacier Bay (Engstrom et al., 1990), and widespread warmth during the early Holocene has been linked to a peak in summer solar insolation (Kaufman et al., 2004). The enhanced seasonality associated with

\footnotetext{
* Corresponding author. U.S. Geological Survey, National Center, Reston, VA 20192, USA.

E-mail address: miriamjones@usgs.gov (M.C. Jones).
}

the early Holocene Thermal Maximum (HTM) is thought to have been instrumental in promoting rapid peatland expansion and accumulation, particularly on the North Slope of Alaska (Mann et al., 2002) and southern Alaska (Jones and Yu, 2010). Cooler temperatures persisted in the mid- to late-Holocene with the onset of Neoglacial cooling (Calkin et al., 2001; Barclay et al., 2009), and mounting evidence exists for a Little Ice Age (LIA) with cooler temperatures and/or wetter climate than today, as documented by the expansion of mountain glaciers across Alaska, including the Kenai Peninsula (Calkin et al., 2001; Barclay et al., 2009). Relatively few studies, however, provide nearly continuous information on the precipitation regime or moisture balance over the Lateglacial and Holocene, particularly for the early Holocene when peatlands were rapidly expanding. 
Several proxy records from Alaska and the Yukon Territory, Canada have demonstrated distinct changes in moisture over the Holocene, which are likely linked to large-scale changes in atmospheric circulation patterns (Fisher et al., 2004; Anderson et al., 2005; Yu et al., 2008; Abbott et al., 2010; Clegg and Hu, 2010; Chipman et al., 2012). However, none of these studies provides a detailed record of moisture and temperature change for the entire Holocene and deglacial interval. Despite the potential of peat cores to provide detailed, long-term records of paleoclimate and paleoenvironmental change, relatively few peat studies have employed stable oxygen isotope analyses to examine paleoenvironmental changes. Here, we use stable oxygen isotope analyses of total organic material (TOM), in addition to plant macrofossils and peat accumulation rates, from a peat core on the Kenai Peninsula, Alaska to examine deglacial and Holocene climate variability for southcentral Alaska. We place our findings in the context of regional synoptic-scale climate patterns and their relation to peatland dynamics.

\section{Study site}

Horse Trail (HT) fen (unofficial name; $6024.9^{\prime}$ N, W150 54.1' W) is located on the Kenai Peninsula to the west of the Kenai Mountains in the lowlands between Skilak Lake and Tustemena Lake
(Fig. 1), Alaska. The Kenai Mountains are composed of Mesozoic bedrock, while the lowlands are composed of alluvial fan and uplifted continental shelf of Tertiary age with a flat to rolling surface formed by glacial events (Rymer and Sims, 1982). Most of the Kenai Peninsula was glaciated during the Last Glacial Maximum (Reger and Pinney, 1997) except for small ice-free refugia scattered throughout parts of the western lowlands (Reger et al., 2007). This area was proposed as a small, unglaciated portion of the Kenai during the Naptowne glaciation (maximum extent $\sim 23,000$ cal yr BP; Reger and Pinney, 1997; Reger et al., 2007). One of these proposed refugia exists between Skilak Lake and Tustemena Lake, but the HT Fen coring location appears to have been glaciated, as the peat record begins 14,500 cal yr BP and bottoms out in glacial till. The earliest part of the record reveals that the HT Fen site began as a shallow pro-glacial lake during the Bølling-Allerød warming (Jones, 2008). Calamogrostis, Carex spp., Equisetum fluviatile, Rubus chamaemorous, and Potentilla palustris comprise the low-lying areas of the fen today. The dominant moss species are Sphagnum squarrosum and Sphagnum angustifolium with Aulacomnium palustre comprising a minor component of moss cover. A narrow streambed cuts through the fen to the west of the coring site, and Alnus spp. border the stream. Higher areas of the fen contain Picea mariana, Ledum palustre, and Vaccinium uliginosum. The water table at the HT Fen site is near the surface of the peat.

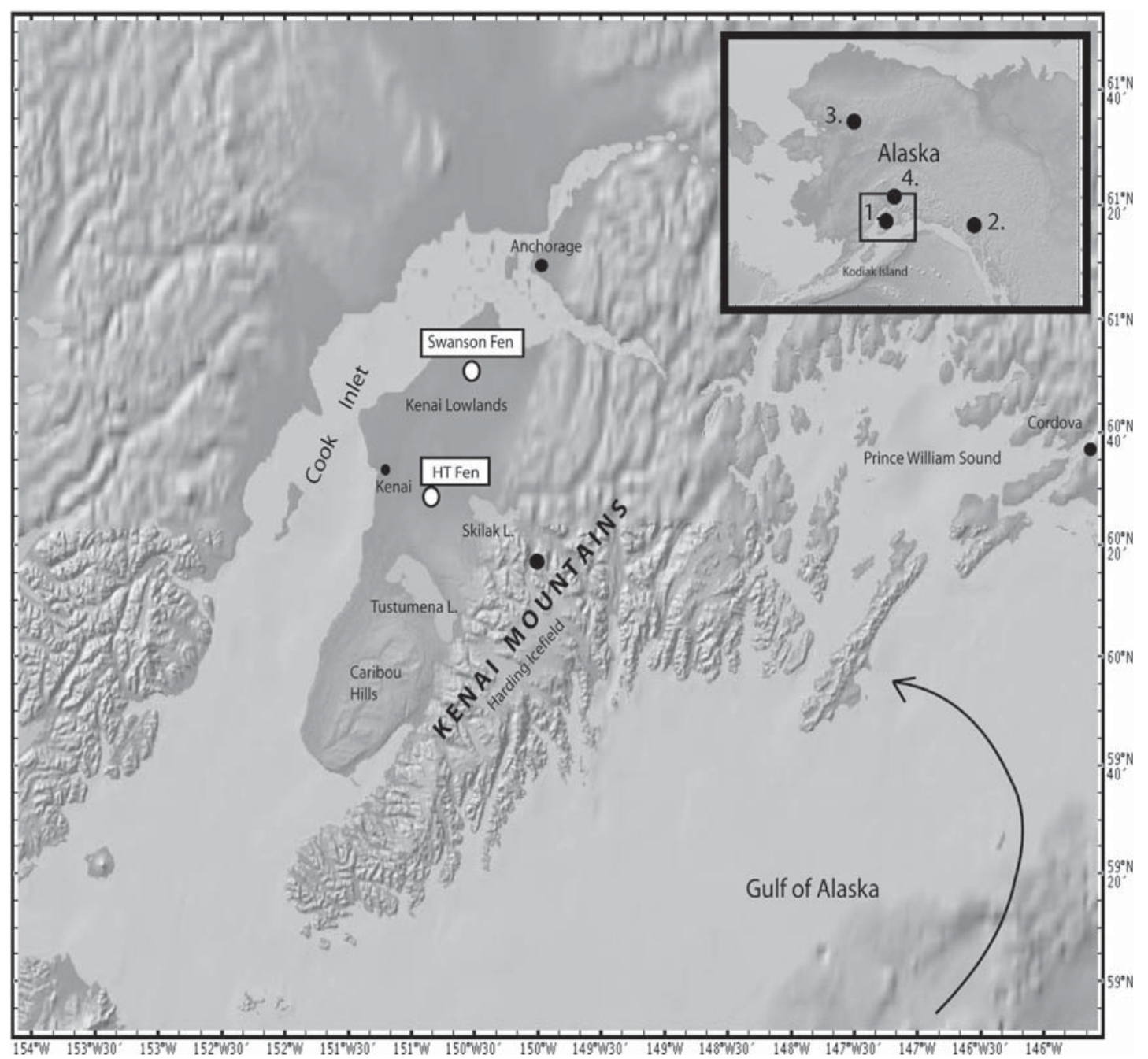

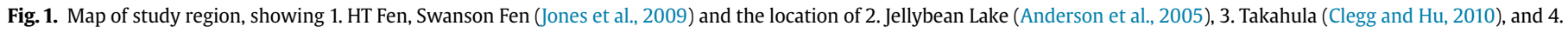
Hundred Mile Lake (Yu et al., 2008), where other oxygen isotope studies were published. The arrow shows the direction of Aleutian Low circulation. 
The climate of the Kenai lowlands is semi-continental, meaning that precipitation is lower, winter temperatures are colder, and summer temperatures are warmer or comparable to surrounding coastal locations. The mean annual temperature at the Kasilof airport is $0.6^{\circ} \mathrm{C}$ and the mean annual precipitation is $46.3 \mathrm{~cm}$, based on the 1971-2000 mean (Alaska Climate Research Center, http:// climate.gi.alaska.edu). Most of the modern-day precipitation falls in the autumn and winter. The Kenai Peninsula weather patterns are influenced by the Aleutian Low (AL), which is a semipermanent low pressure system that builds over the North Pacific during the late fall through the winter (Overland et al., 1999). The Aleutian Low moves from its position in the Bering Sea eastward to the Gulf of Alaska in the winter and early spring months when it intensifies, and westward toward the Aleutian Islands in July, when it weakens (Trenberth and Hurrell, 1994). The AL exhibits decadal variability in its strength and position (Overland et al., 1999), and a stronger AL is linked to warmer sea surface temperatures (SSTs) and greater precipitation on the Kenai Peninsula (Trenberth and Hurrell, 1994). The AL has been linked to the Pacific North American (PNA) mode of atmospheric variability, and the Arctic Oscillation (AO) (Overland et al., 1999), which affect the polar vortex and influence the arctic climate system (Moritz et al., 2002) as well as the Pacific Decadal Oscillation (Mantua et al., 1997). In the summer, the East Asian Trough and the Subtropical High pressure cells influence summer moisture in the region (Mock et al., 1998).

\section{Methods}

A 4.5-m long peat core was taken from HT Fen in August 2006 with a Dachnowski peat corer. The core was sectioned at $2-\mathrm{cm}$ intervals. Two cubic centimeters of sediment from each peat sample were analyzed for wet bulk density measurements. The samples were then dried at $100{ }^{\circ} \mathrm{C}$ to estimate the moisture content and then processed for loss-on-ignition (LOI) at $550{ }^{\circ} \mathrm{C}$ for $2 \mathrm{~h}$ using standard procedures (Dean, 1974). Dry bulk density measurements were calculated from the original 2-cc sample volume and dry mass. The LOI and bulk density were multiplied to obtain the ashfree bulk density. The carbon accumulation rate was calculated from the ash-free bulk density, assuming that 0.52 (Clymo et al., 1998) of peat is carbon. Macrofossils were analyzed from $4 \mathrm{~cm}^{3}$ by sieving through a $250-\mu \mathrm{m}$ screen according to methods of Watts and Winter (1966), Peteet (1986), and Janssens (1990), identifying seeds, fruits, needles, stems, bryophytes, and charcoal. Macrofossils were picked and counted using a binocular microscope. Mosses picked from the macrofossil analysis were isolated and mounted onto slides for identification at 400X using a binocular microscope. Species were identified using Crum and Anderson (1981), Janssens (1983), and from a reference collection of mosses from the Kenai Peninsula, housed at the Kenai National Wildlife Refuge. Moss species were identified at each sample interval, but not quantified. At HT Fen, the matrix was quantified from a 2-ml slurry of sample based on the number of moss leaves, moss stems, moss stems and leaves, Cyperaceae (sedge) parts, vascular plant parts (i.e. leaves), wood, and Equisetum rhizomes (after Yu et al., 2003). The matrix for each depth was counted twice on two different samples and averaged to account for variation in each 2-ml slurry. Selected macrofossils were dated using AMS radiocarbon dating techniques at Lawrence Livermore National Laboratory, California. Radiocarbon ages were calibrated to calendar ages using IntCal2009 (Reimer et al., 2009). We generated an age model using linear interpolation of calibrated radiocarbon dates (Jones, 2008).

Bulk sediment samples were taken from each 2-cm core section for stable oxygen isotope analyses of total organic material (TOM), according to previously published protocols (Wooller et al., 2007a, 2007b; Monacci et al., 2009). We also selected a sub-set of 13 samples from downcore to extract cellulose (using the method described by Wolfe et al., 2001) for stable oxygen isotope analyses that included large differences in the relative abundances of peat types (i.e. sedges, Tomenthypnum nitens, Sphagnum spp.) to compare with the $\delta^{18} \mathrm{O}$ values derived from TOM, as previously conducted on peat cores (Monacci et al., 2009). Analytical precision associated with the stable oxygen isotope analyses was $\leq 0.6 \%$ and is expressed as one standard deviation from the mean based on the results from multiple $(n=10)$ analyses of a laboratory standard (benzoic acid, Fisher Scientific, Lot No 947459) conducted during the run of samples. A suite of international standards (NBS N-1, NBS-18, NBS-19) were analyzed with the run (measured vs. expected $r^{2}=0.99$ ) to allow the calibration of the data relative to Vienna Standard Mean Ocean Water (VSMOW).

\section{Results}

\subsection{Chronology}

We obtained 9 AMS radiocarbon dates from plant macrofossils (Table 1) from the HT Fen core. We rejected the basal age at $424 \mathrm{~cm}$, because the calibrated age is almost 5000 years older than the age at $420 \mathrm{~cm}$. The basal sample was dated on a Potamogeton seed and a test with $\mathrm{HCl}$ revealed that the basal two samples contained carbonate. Therefore, it is likely that aquatic plants at this depth interval were taking up old carbon. The diffusion rate of $\mathrm{CO}_{2}$ in water is $10^{4}$ times lower than in air, and thus $\mathrm{CO}_{2}$ may be limiting in aquatic systems, resulting in $\mathrm{HCO}_{3}^{-}$uptake (Bodner, 1994). A date of $11,805 \pm 40{ }^{14} \mathrm{C}$ BP was attained at $420 \mathrm{~cm}, 4 \mathrm{~cm}$ above the basal date. An age reversal in HT Fen occurs between $390 \mathrm{~cm}$ and $418 \mathrm{~cm}$, despite the use of Carex macrofossils (Table 1). The date at $390 \mathrm{~cm}$ was also rejected, because it seems too old, based on the increase in LOI that is most likely associated with Holocene warming consistent with three other peat core records from across the Kenai Peninsula (Jones et al., 2009; Jones and Yu, 2010). The small size of the sample and the large counting error suggest that contamination could have more easily occurred. A significant decrease in the peat accumulation rate occurs between $8775 \pm 232\left(7850 \pm 40{ }^{14} \mathrm{C}\right)$ at $142 \mathrm{~cm}$ and $1570 \pm 60\left(1660 \pm 35{ }^{14} \mathrm{C}\right)$ cal yr BP at $94 \mathrm{~cm}$. The presence of inorganic material results in a decrease in LOI during this part of the record, consistent with the decrease at Swanson Fen on the Kenai Lowlands (Jones et al., 2009), where it is radiocarbon dated between $\sim 5000-2000$ cal yr BP. This decrease in LOI may be attributable to tephra, as numerous volcanic eruptions have been recorded in a Kenai lake record between 4000-2000 cal yr BP (de Fontaine et al., 2007) or an increase in either Aeolian silt deposition. Microscopic analysis of the larger grains does indicate a presence of

Table 1

Radiocarbon dates from Horse Trail (HT) Fen. Italicized dates were rejected.

\begin{tabular}{lclrc}
\hline Lab no. & $\begin{array}{l}\text { Depth } \\
(\mathrm{cm})\end{array}$ & Material dated & \multicolumn{1}{l}{$\begin{array}{l}{ }^{14} \text { C Age } \\
\text { (year BP) }\end{array}$} & $\begin{array}{l}\text { Calibrated } \\
\text { 2-sigma age } \\
\text { (cal yr BP) }\end{array}$ \\
\hline CAMS-136981 & $34-36$ & Betula wood & $730 \pm 30$ & $690 \pm 35$ \\
CAMS-136982 & $94-96$ & Charcoal (wood) & $1660 \pm 35$ & $1570 \pm 60$ \\
CAMS-135723 & $142-144$ & Menyanthes seed & $7850 \pm 40$ & $8659 \pm 115$ \\
CAMS-135724 & $178-180$ & Menyanthes seed & $8220 \pm 35$ & $9185 \pm 110$ \\
CAMS-135725 & $208-210$ & Menyanthes seed & $8360 \pm 40$ & $9380 \pm 95$ \\
CAMS-135726 & $252-254$ & Menyanthes seed & $8705 \pm 35$ & $9659 \pm 110$ \\
CAMS-135727 & $316-318$ & Menyanthes seed & $9455 \pm 35$ & $10,680 \pm 105$ \\
CAMS-135795 & $352-354$ & Carex, Menyanthes & $9580 \pm 70$ & $10,940 \pm 230$ \\
& & seeds & $11,820 \pm 130$ & $13,670 \pm 280$ \\
CAMS-135728 & $390-392$ & Carex seed & $11,780 \pm 60$ & $13,615 \pm 155$ \\
CAMS-131918 & $418-420$ & Carex seeds & $11,805 \pm 40$ & $13,665 \pm 120$ \\
CAMS-136980 & $420-422$ & Carex seeds & $15,620 \pm 60$ & $18,880 \pm 105$ \\
CAMS-136983 & $424-426$ & Potamogeton seed & 15,605 \\
\hline
\end{tabular}




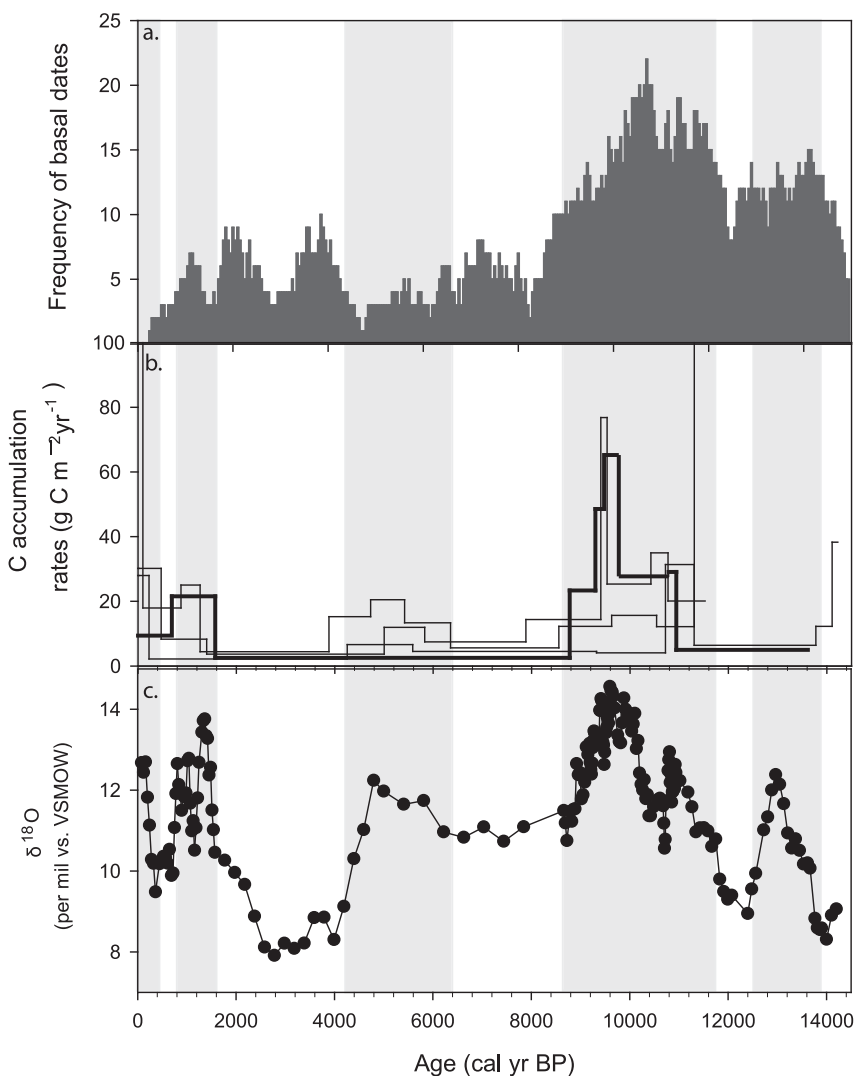

Fig. 2. a.) Frequency of peat basal dates from peat cores across Alaska modified from Jones and Yu (2010) to exclude old bulk ages with large error bars, b) C accumulation rates from four peat cores across the Kenai Lowlands modified from Jones and $\mathrm{Yu}$ (2010); HT Fen is shown in bold c.) $\delta^{18} \mathrm{O}_{\text {TOM }}$ recorded in the HT Fen peat core. The gray bars are associated with a more enriched $\delta^{18} \mathrm{O}_{\text {Tом }}$ signature, roughly corresponding to greater peatland expansion and peat accumulation.

volcanic glass during this period. If the base of the tephra in HT Fen is between 5000-4000 years old, it means that only $20 \mathrm{~cm}$ accumulated in HT Fen between $8660 \mathrm{cal} \mathrm{yr}$ BP at $142 \mathrm{~cm}$ and the inferred date of $5000 \mathrm{cal} \mathrm{yr} \mathrm{BP}$ at $125 \mathrm{~cm}$, signifying that either sediment accumulation was low during this time or that a hiatus exists. Abundant charcoal during this interval, in addition to the absence of mosses and abundance of detrital peat, suggests that the climate was dry. Since our basal age was rejected, our age model linearly extrapolates the lowermost age to the bottom of the core.

\subsection{Macrofossil analysis}

Peat-forming mosses comprise the majority of the HT Fen core, with detrital peat/gyttja near the base. The LOI for the HT Fen (Fig. 3) core displays a remarkable similarity with that of Swanson Fen (Jones et al., 2009) and carbon accumulation rates follow the same pattern as three other peat cores from the Kenai Peninsula (Jones and Yu, 2010; Fig. 2b), including the early Holocene increase to $>80 \%$, the decline to values between 60 and $70 \%$ coinciding with the tephra or other mineral matter seen in both records, and the late Holocene increase to $>80 \%$. The core was divided into four zones according to the most prominent changes in plant macrofossil assemblages.

\subsubsection{Zone 1: Lateglacial (14,200-11,500 cal yr BP)}

HT Fen is alkaline during the Lateglacial, with abundant oospores of the carbonate-precipitating algae Chara (Fig 3).
Zannichellia (an alkaline indicator and aquatic species), Daphnia ephippia (winter eggs of pond cladocerans), Hippuris vulgaris, Menyanthes trifoliata, and Carex spp. seeds all suggest an aquatic to semi-aquatic environment (Fig. 3). Betula spp. leaf fragments and Empetrum nigrum seeds were found $\sim 420 \mathrm{~cm}$. The leaf fragments are difficult to distinguish, although they most resemble Betula nana.

M. trifoliata increases following the disappearance of Chara oospores, possibly indicating a shallower water depth as the depression began infilling with peat. Empetrum and Caryophyllaceae seeds $(390 \mathrm{~cm})$ suggest a relatively cold and dry YD interval. Warnstorfia exannulata and brown moss leafless stems, presumably of W. exannulata (Fig. 3), comprise a significant portion of the matrix, along with sedge remains (Fig. 3). Sphagnum and T. nitens first appear in the record at $\sim 410 \mathrm{~cm}$, indicating a shoaling of the water table (Fig. 3).

\subsubsection{Zone 2a. Early Holocene (11,500-10,500 cal yr BP)}

The matrix at the onset of the Holocene in HT Fen consists primarily of sedge, but Sphagnum, T. nitens, and woody material are also abundant (Fig. 3). The likely source of the wood is Betula spp. because of the presence of Betula seeds and Betula leaves (Fig. 3). Between $330 \mathrm{~cm}$ and $320 \mathrm{~cm}$ (10,900-10,700 cal yr BP), these Betula remains are most abundant and are concomitant with fungal Cenoccocum sclerotia, which may suggest water transport from terrestrial sources (Birks, 2000). Mosses do not comprise a significant portion of the matrix (Fig. 3), though diverse alkaline, wet fen bryophytes are present, including Limprichtia revolvens, $W$. exannulata, A. palustre, Rhizomnium gracile, Calliergon giganteum, Helodium blandowii, Paludella squarrosa, Scorpidium scorpiodes (Fig. 3). Sphagnum and T. nitens were abundant during the YD interval, but are almost absent in zone 2a. This sequence of species occupies different microtopographical niches from submerged (S. scorpiodes) to emergent (L. revolvens) extreme-rich fens and moderate-rich fens (Gignac et al., 1991) and may indicate a period of water level fluctuations.

\subsubsection{Zone $2 b$. Early Holocene ( 10,500 to $\sim 5000$ cal yr BP)}

In HT Fen, T. nitens and Sphagnum spp. increase in abundance and the peat is well preserved from 10,700-8700 cal yr BP (Fig. 3). $P$. squarrosa leaves are found throughout this zone, but are not abundant (Fig. 3). C. giganteum is present near the base of this zone (Fig. 3), but declines when Sphagnum and T. nitens become more abundant. $M$. trifoliata seeds are consistently present during this period but increase when $C$. giganteum decreases, suggesting an emergence of a wet peat carpet, rather than pools of deeper water as at the beginning of the Holocene, and a progression of the site from a carbonate-rich pool to a moderately rich fen (Fig. 3). $L$. palustre and Vaccinium oxycoccus leaves occur intermittently from $280 \mathrm{~cm}$ to $210 \mathrm{~cm}$ ( $\sim 10,000$ to $\sim 9500 \mathrm{cal} \mathrm{yr} \mathrm{BP})$, coincident with increasing Sphagnum and T. nitens (Fig. 3), which suggests a lowering of the water table $\sim 9600$ cal yr BP. Sphagnum spp. are less abundant than $T$. nitens at the beginning of zone $2 \mathrm{~b}$, but Sphagnum increases and $T$. nitens decreases in the matrix $\sim 9400$ cal yr BP. T. nitens increases again $8800 \mathrm{cal}$ yr before disappearing after this zone.

\subsubsection{Zone 3. mid- to late-Holocene ( $5000-2000$ cal yr BP)}

In HT Fen, an interval of increased tephra in the record from $140 \mathrm{~cm}$ to $86 \mathrm{~cm}$ ( $\sim 5000$ to $2000 \mathrm{cal} \mathrm{yr} \mathrm{BP})$ coincides with a disappearance of $T$. nitens and an emergence of more minerotrophic moss species (A. palustre, Calliergon stramineum, C. giganteum, $H$. blandowii, $R$. gracile), perhaps related to a change in chemistry resulting from $40 \mathrm{~cm}$ of increased tephra (Fig. 3). These minerotrophic moss species persist in the core above and thus later than 


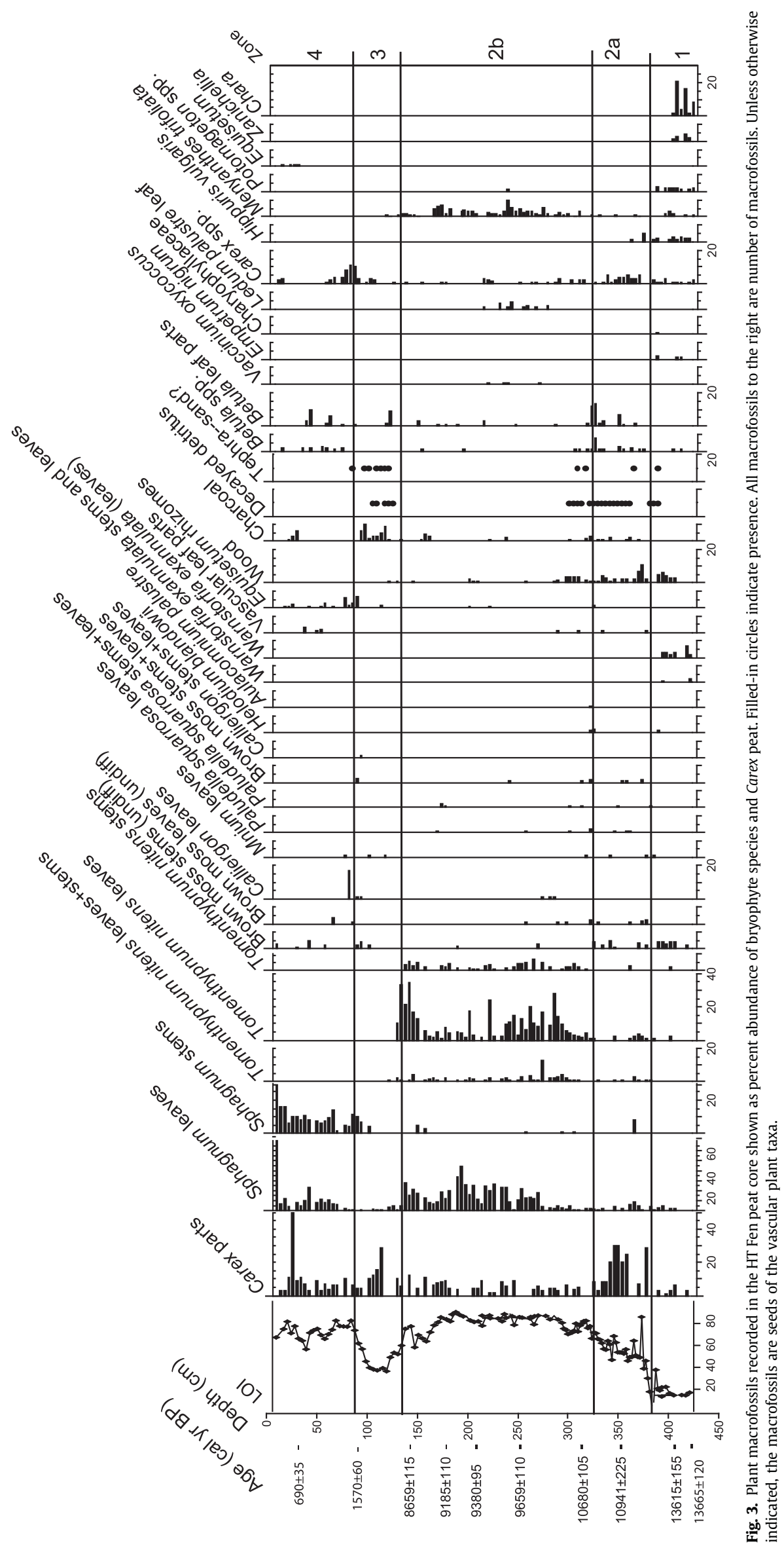


the tephra, as indicated by microscopic analysis and LOI data. Carex remains predominant in the matrix and peak near $115 \mathrm{~cm}$, though the peat is not well preserved. Charred Picea needle tips are found at $96 \mathrm{~cm}$ and $94 \mathrm{~cm}$ coincident with an increase in charcoal (Fig 3). Bryophyte abundance decreases during this interval $(\sim 110 \mathrm{~cm}-$ $\sim 94 \mathrm{~cm}$ ), with predominantly stems visible, suggesting that decomposition increased as conditions became drier, and a hiatus may be present. The presence of $R$. gracile leaves suggests a lowering of the water table, as they are shade reliant and common in P. mariana muskegs (Crum and Anderson, 1981). However, the presence of Calliergon spp. and leaves indicate a wetter environment, such as temporary pools and carpets (Crum and Anderson, 1981). Thus, this assemblage may signify a period of fluctuating water levels.

\subsubsection{Zone 4. Late Holocene (2000-1500 cal yr BP-Present)}

In HT Fen, Equisetum rhizomes persist for the top $\sim 90 \mathrm{~cm}$ of the core and Daphnia ephippia appear again at $60 \mathrm{~cm}$. E. fluviatile is currently abundant on the site, and if this same species was present in the past, both the Equisetum and the Daphnia would suggest an increase in the water table, although increased $B$. nana leaves and Betula spp. seeds suggest fen hummocks (Fig. 3). C. stramineum, a species indicative of a high water table, is only present at the bottom of this zone. Sphagnum dominates the matrix in this zone (Fig. 3), and Betula macrofossils, including seeds and leaves, increase in abundance (Fig. 3). Carex spp. seeds are only found in the top $10 \mathrm{~cm}$ (Fig. 3), although other sedge remains are found throughout this zone, increasing in abundance $\sim 25 \mathrm{~cm}$ where Sphagnum decreases in abundance.

\subsection{Apparent carbon accumulation rates}

The apparent rates of carbon accumulation from HT Fen, as well as Swanson Fen (Jones et al., 2009; Jones and Yu, 2010) and two other Kenai Lowland sites (Kenai Gasfield and No Name Creek) were previously shown by Jones and Yu (2010). To summarize, the time-weighted average rate of Holocene carbon accumulation at HT Fen is $10.67 \mathrm{~g} \mathrm{C} \mathrm{m}^{-2} \mathrm{yr}^{-1}$, which is lower than other boreal Holocene peat deposits, which range from 12 to $46 \mathrm{~g} \mathrm{C} \mathrm{m}^{-2} \mathrm{yr}^{-1}$ across the boreal region (Yu et al., 2009; Fig 2b). The early Holocene represents the period of highest carbon accumulation, where carbon accumulation rates increase from an early Holocene $\sim 28 \mathrm{~g} \mathrm{C} \mathrm{m}^{-2} \mathrm{yr}^{-1}$ to $\sim 65 \mathrm{~g} \mathrm{C} \mathrm{m}^{-2} \mathrm{yr}^{-1}$ from 10,900 cal yr BP to 10,700 cal yr BP, before declining steadily from $\sim 49 \mathrm{~g} \mathrm{C} \mathrm{m}^{-2} \mathrm{yr}^{-1}$ near $9200 \mathrm{cal} \mathrm{yr} \mathrm{BP}$ to $\sim 23 \mathrm{~g} \mathrm{C} \mathrm{m}^{-2} \mathrm{yr}^{-1}$ and an average of $<5 \mathrm{~g} \mathrm{C} \mathrm{m}^{-2} \mathrm{yr}^{-1}$ by 8700 cal yr BP. After 8700 cal yr BP, average carbon accumulation rates decrease to $2.5 \mathrm{~g} \mathrm{C} \mathrm{m}^{-2} \mathrm{yr}^{-1}$ in HT Fen, before increasing again to $21.6 \mathrm{~g} \mathrm{C} \mathrm{m}^{-2} \mathrm{yr}^{-1}$ at $1570 \mathrm{cal} \mathrm{yr} \mathrm{BP.} \mathrm{The}$ highest rates of carbon accumulation during the early Holocene also coincide with the period of most rapid peatland expansion in Alaska (Fig 2a; Jones and Yu, 2010).

\subsection{Oxygen isotope analysis}

The $\delta^{18} \mathrm{O}$ values derived from analyses of TOM $\left(\delta^{18} \mathrm{O}_{\text {TOM }}\right)$ differ by up to $9 \%$ over the course of the Holocene (Fig. 2 c), which is much greater than the analytical precision $(0.6 \%)$. We found a strong positive relationship $\left(R^{2}=0.689\right)$ between $\delta^{18} \mathrm{O}_{\text {TOM }}$ values and the $\delta^{18} \mathrm{O}$ values derived from analyses of extracted cellulose $\left(\delta^{18} \mathrm{O}_{\text {cellulose }}\right.$ ) (Fig. 4 ), which indicates that the $\delta^{18} \mathrm{O}_{\text {TOM }}$ variation is a reliable proxy for $\delta^{18} \mathrm{O}_{\text {cellulose }}$. We also found that the $\delta^{18} \mathrm{O}_{\text {TOM }}$ variation is weakly correlated with the predominant vegetation types comprising the peat matrix (Carex sp. $R^{2}=-0.32$, Sphagnum $R^{2}=0.22$, $T$. nitens $R^{2}=0.32$ ), implying that the variation was not solely driven by the source of organic matter comprising the peat.

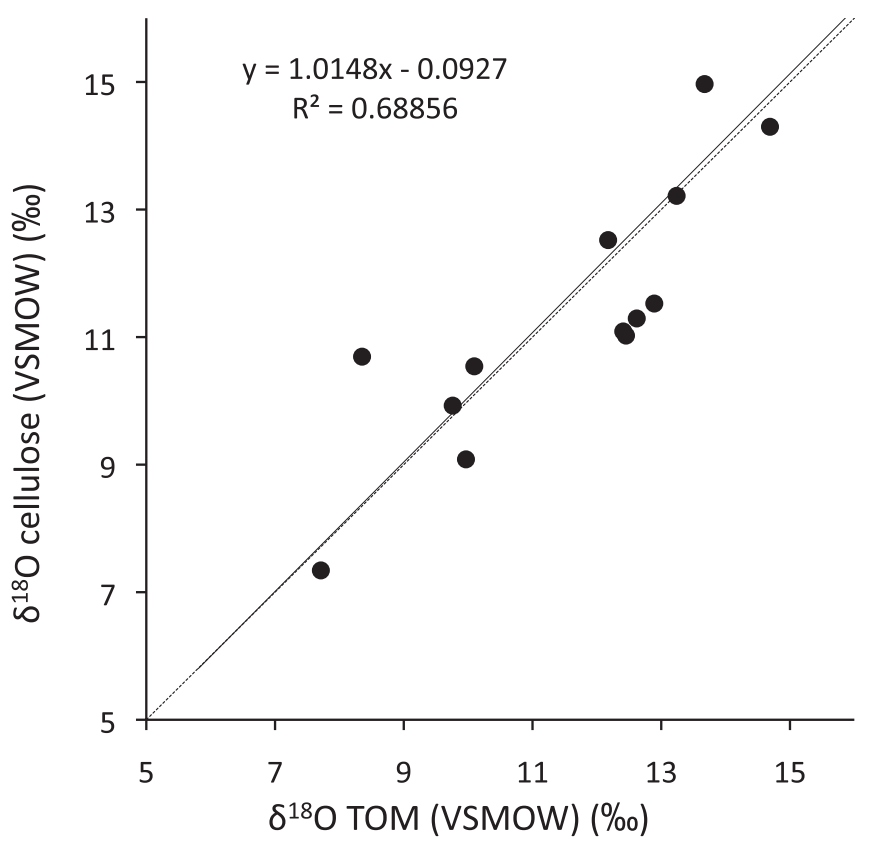

Fig. 4. The relationship between $\delta^{18} \mathrm{O}_{\text {том }}$ and $\delta^{18} \mathrm{O}_{\text {cellulose values from selected samples }}$ spanning the entire peat core. The solid line is a linear regression fit to the data (equation of the line and $R^{2}$ fit statistic shown), and the dashed line represents a 1:1 relationship. Samples were selected to include isotopic highs and lows across the record, as well as samples that changed in dominance from Sphagnum and Tomenthypnum nitens (bryophytes) to Carex spp. (vascular).

The HT Fen record begins with a $\delta^{18} \mathrm{O}_{\mathrm{TOM}}$ value of $\sim 8.0 \%$ at 14,000 cal $\mathrm{yr} \mathrm{BP}$, before increasing to a peak of $12.5 \%$ at $\sim 13,000$ cal yr BP, corresponding with the timing of the BøllingAllerød warming. The $\delta^{18} \mathrm{O}_{\mathrm{TOM}}$ values then steadily decline to a minimum of $9.0 \%$ at 12,400 cal yr BP during the YD interval. The end of the YD interval is characterized by an abrupt increase in $\delta^{18} \mathrm{O}_{\text {TOM }}$ values to $\sim 11 \%$ and continues to increase to $12.6 \%$ at $10,900 \mathrm{cal}$ yr BP. The early Holocene increase in $\delta^{18} \mathrm{O}_{\mathrm{TOM}}$ values is interrupted by a decrease of $\sim 2.0 \%$ until 10,000 cal yr BP. The early Holocene $\delta^{18} \mathrm{O}_{\text {TOM }}$ values peak between 10,000 and 9000 cal yr BP $(\sim 13.0-14.6 \%)$, with the highest values $(14.7 \%)$ centered around 9500 cal yr BP. The $\delta^{18} \mathrm{O}_{\text {TOM }}$ values drop abruptly at 8700 cal yr BP to $10.8 \%$ and remain at $\sim 11-12 \%$ until $\sim 5400$ cal yr BP when they increase to $\sim 12.0 \%$ until 4800 cal yr BP. The $\delta^{18} \mathrm{O}_{\mathrm{TOM}}$ values reach their lowest point $(\sim 8.0 \%)$ since the YD interval from 4000 to $\sim 2500$ cal yr BP. Much higher and highly variable $\delta^{18} \mathrm{O}_{\text {TOM }}$ values persist from 1570-800 cal yr BP (fluctuating between $\sim 10.5$ and $14.0 \%$ ) before decreasing to $\sim 10.0 \%$ between 690 and 280 cal yr BP. From there, values increase to near $13.0 \%$ at present.

\section{Discussion}

\subsection{Paleoclimate interpretations from peat lithology and plant macrofossils}

The HT Fen record begins $>14,000$ cal yr BP as a shallow pond with abundant Potamogeton macrofossils and undifferentiated Amblystegiaceae (brown) mosses. During the Bølling-Allerød, HT Fen is characterized by rich fen conditions with a relatively high water table position, but peat accumulation rates remain low. The highest rates of peat accumulation occur during the early Holocene, which have been attributed to warm early Holocene summers related to the maximum in insolation seasonality (Jones and Yu, 2010). The high accumulation of well-preserved peat in the HT Fen record (this study) and other Kenai Peninsula peatlands (Jones 
et al., 2009; Jones and Yu, 2010), as well as the rapid expansion of peatlands across Alaska during the early Holocene (Fig. 2; Jones and Yu, 2010) suggests that conditions were wet enough to not only sustain peatlands, but also to allow them to proliferate. This lies in contrast to several studies that allude to a wetter YD (Kaufman et al., 2010), but overall drier conditions during the early Holocene (Anderson et al., 2006; Clegg and Hu, 2010; Kaufman et al., 2010). From a peatland perspective, the dominance of $T$. nitens and Sphagnum spp. in the HT Fen core indicate moderately rich fen conditions persisted and that the water table remained near or slightly below the surface. The rapid accumulation of this extremely well-preserved peat, not only in this record, but in other peatlands from a variety of settings across the Kenai lowlands (Jones et al., 2009; Jones and Yu, 2010) is further indication that conditions were warm enough to allow high net primary productivity (NPP) and waterlogged enough to prevent decomposition before peat burial into the catotelm.

The abrupt change in peat lithology from bryophyte-dominated peat to sedge-dominated peat, as well as a decrease in peat preservation and increased charcoal, beginning $\sim 8500$ cal yr BP suggests a significant change in regional moisture availability occurred with much drier conditions at the fen from 8500 to $\sim 1600$ cal yr BP. The abundant charcoal in the record during this time interval, coupled with the detrital nature of the peat and extremely low accumulation, suggests a hiatus exists in the peat record. However, an absence of charred peat (as opposed to macroscopic charcoal fragments) suggests fire may not have directly consumed the peat, but that overall drier conditions, combined with greater fuel load, related to climate-driven shifts in vegetation communities, may have increased fires during this period. This finding is consistent with lake studies of Holocene fire frequency from Alaska that show greater fire frequency beginning $5.4 \mathrm{ka}$ in Interior Alaska, potentially related to the establishment of black spruce ( $P$. mariana) (Lynch et al., 2003). Peat accumulation rates in three other peatlands from the Kenai Peninsula show a similar decline during this portion of the Holocene, and overall new peatland formation slows (Fig. 2a; Jones and Yu, 2010). Another possibility for an overall drier peat surface during this interval is related to the orbitally driven decline in temperatures during the mid-Holocene, often referred to as Neoglaciation (e.g. Mann et al., 1998). Cooler temperatures on the Kenai lowlands, coupled with drier conditions, may have resulted in a mid-Holocene aggradation of permafrost, which has been observed in other peatlands in Alaska (Hunt et al., 2013) and across the circum-Arctic.

The increase in peat accumulation rates, along with a return of Sphagnum-dominated peat in HT Fen after 1600 cal yr BP is consistent with greater peat accumulation and increase in bryophytic peat in other Kenai Peninsula records (Jones et al., 2009; Jones and Yu, 2010), suggesting a return to moister conditions. One other dry period $\sim 690$ cal yr BP, associated with abundant charcoal and an increase in sedge peat, coincides with the timing of the Little Ice Age, suggesting the effects of this climate perturbation resulted in drier conditions on the Kenai Peninsula, at least during the growing season when peatlands are productive.

\subsection{Oxygen isotopes as paleoenvironmental proxies in peat}

Although peat cores have been frequently used as paleoecological and paleoclimate archives, relatively few studies have taken advantage of peat cores for the analysis of stable oxygen isotopes. One advantage to stable isotope records from peat cores is the potential for them to provide long-term records, unlike records from lakes, which rely on a constant abundance of a proxy (e.g. chironomids, ostracods, bivalves, calcite) to analyze for their stable oxygen isotope composition. Interpreting stable isotopes from peat core records can be difficult because of changes in the degree of peat preservation, species-specific differences and changes in assemblages, and unknown biochemical pathways within plants in the cores. Differences in decay rates between species in the same environment could lead to systematic errors in the preservation of the stable isotope signature (Loader et al., 2007; Kaislahti Tillman et al., 2010). Thus, the lack of records with the same peat preservation and species assemblages for the entirety of the peat core makes continuous paleoclimate interpretations nearly impossible.

To date, most studies have used cellulose extracted from Sphagnum moss remains to identify temporal changes in $\delta^{18} \mathrm{O}$ values and have recorded offsets of up to $0.9 \%$ of the $\delta^{18} \mathrm{O}$ values among different portions of the Sphagnum plant (i.e. stems vs. branches) (Brenninkmeijer et al., 1982; Ménot-Combes et al., 2002; Moschen et al., 2009), and this offset is quasi-constant between isotope values of branches and stems of Sphagnum fuscum mosses and whole plant material and $\alpha$-cellulose (Moschen et al., 2009; Kaislahti Tillman et al., 2010). We found a strong positive relationship between $\delta^{18} \mathrm{O}_{\text {TOM }}$ and $\delta^{18} \mathrm{O}_{\text {cellolose, implying that our more }}$ temporally resolved $\delta^{18} \mathrm{O}_{\text {TOM }}$ record is a reliable proxy for $\delta^{18} \mathrm{O}_{\text {cel- }}$ lolose variation (Fig. 4). A maximum offset between whole plant and

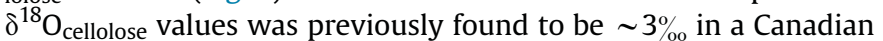
Arctic peat core (Kaislahti Tillman et al., 2010), and the offset was consistent in direction, with $\alpha$-cellulose consistently lighter than the whole plant values (Kaislahti Tillman et al., 2010). The extraction of cellulose, however, is time consuming and requires special laboratory equipment (Borella et al., 1999; Ménot and Burns, 2001; Cullen and Grierson, 2006; Skrzypek et al., 2007), and several studies have successfully interpreted paleoclimate records from stable isotopes in peat and lake sediment using TOM (Ménot and Burns, 2001; Loader et al., 2007; Skrzypek et al., 2007; Monacci et al., 2009; Wooller et al., 2007a,b). Because of the consistency of direction and the maximum of $3 \%$ offset in bulk plant material and $\alpha$-cellulose extraction (Kaislahti Tillman et al., 2010), our interpretation of changes greater than this magnitude can be ascribed to changes in climate that occurred during the Lateglacial and Holocene.

The controls of the $\delta^{18} \mathrm{O}$ values in the plant remains in peat cores are temperature, precipitation, and evaporation, but precipitation and evaporation are the most important factors (Deniro and Epstein, 1979; Kaislahti Tillman et al., 2010). The large amplitude changes observed in the HT Fen record, along with the weak correlation between dominant peat type and $\delta^{18} \mathrm{O}_{\text {TOM }}$ values, suggest that the $\delta^{18} \mathrm{O}$ signal is related to both changes in temperature and moisture patterns. Higher $\delta^{18} \mathrm{O}_{\mathrm{TOM}}$ values during the BøllingAllerød Warming ( $\sim 14,000$ to 12,900 cal yr BP) and the early Holocene (11,600 to $\sim 8700$ cal yr BP) and lower $\delta^{18} \mathrm{O}_{\mathrm{TOM}}$ values during cooler intervals such as the YD (13,000 to 11,600 cal yr BP) suggest temperature can at least partially explain some of the isotopic variation in the HT Fen record. The magnitude of the $\delta^{18} \mathrm{O}_{\mathrm{TOM}}$ shifts, however, is too large to account for temperature alone $\left(0.6 \%\right.$ per ${ }^{\circ} \mathrm{C}$ between meteoric precipitation and temperature at mid- to high latitudes; Dansgaard, 1964).

Evaporative fractionation can be large and often mask the net precipitation signal. This is particularly true in closed-basin lakes that respond strongly to the effects of evaporation, resulting in a heavier isotopic signature in the lake sediments (Leng and Marshall, 2004). Although far fewer studies exist on oxygen isotope fractionation of peat mosses, studies have shown that the evaporative fractionation effect is much stronger in hummockforming species rather than submerged species (Zanazzi and Mora, 2005). If the system were largely evaporative during the early Holocene, this would suggest drier surface conditions would have existed. We know from the macrofossil record, however, that rapid accumulation of well-preserved T. nitens and Sphagnum spp. 
peat suggests a stable water table close to the surface existed over the course of the early Holocene, meaning an overall wetter peat surface during the growing season in the lowlands. Therefore, this suggests that the observed shifts in oxygen isotopic fractionation are most likely largely explained by shifts in precipitation source water.

Precipitation data indicate that maritime air masses are more enriched in ${ }^{18} \mathrm{O}$ while Interior air masses are more depleted by up to 10\% (IAEA/WMO, 2001; Anderson et al., 2005), which can be explained by the Rayleigh distillation when air masses travel over mountain ranges and the heavier isotopes are rained out. The primary system that influences the precipitation on the Kenai Peninsula is the AL, a semi-permanent low-pressure system that develops in the winter months and which changes its strength and position on decadal to multi-decadal timescales (Trenberth and Hurrell, 1994). As such, the trajectory and strength of the AL likely played an important role in the isotopic signature of the water taken up by the peatland vegetation. Because moisture delivered to the Kenai Lowlands is first rained out on the eastern side of the Kenai Mountains due to the cyclonic movement of storms around the AL pressure center, stronger rain out would result in more depletion during a strengthened $\mathrm{AL}$ (Anderson et al., 2005). Numerous studies have attributed shifts in $\delta^{18} \mathrm{O}$ paleorecords to changes in circulation patterns, particularly associated with the strength and position of the AL (Fisher et al., 2004; Anderson et al., 2005; Yu et al., 2008; Schiff et al., 2009). The $\delta^{18} \mathrm{O}_{\text {TOM }}$ pattern observed in HT Fen over the Holocene is broadly consistent with the nearly 8000-year $\delta^{18} \mathrm{O}$ record from Jellybean Lake in the Yukon Territory, Canada, suggesting a strong influence and consistency in the precipitation effect of the AL over the
Holocene in these two locations located on the leeward side of their respective mountain ranges.

Anderson et al. (2005) ascribed a negative shift in $\delta^{18} \mathrm{O}$ values to a stronger/eastward AL and a positive shift to a weaker/westward AL, which can be explained by a stronger rain out of the heavier isotopes on the leeward side of the mountains during a strong AL, leaving locations in the rain shadow, such as Jellybean Lake, in the Yukon Territory and HT Fen on the Kenai Peninsula, with precipitation relatively depleted in ${ }^{18} \mathrm{O}$. The temporal agreement in isotopic shift between Jellybean Lake and HT Fen (Fig. 5), as well as an early Holocene shift in a lake record from the Matanuska Valley (Yu et al., 2008) suggests synoptic-scale circulation changes influenced the precipitation in the North Pacific. Given the agreement in the two records over the last $\sim 7000$ years (Fig. 5), applying the same relationship to the HT Fen record, higher rates of accumulation of well-preserved byrophytic peat are associated with a weaker AL, while lower rates of peat accumulation and decreased peat preservation are associated with a strengthened AL. Because peatlands are productive during the growing season, this suggests that the winter precipitation (strong $\mathrm{AL}$ ) is largely unimportant for peat growth and implies that summer precipitation is more important during years of a weak AL.

The high rates of peat accumulation and peatland expansion during periods of inferred weak AL conditions suggest that summer precipitation had to have been higher to allow for rapid peat accumulation. For the two weather stations with isotopic measurements of meteoric precipitation (Bethel, AK in southwest Alaska and Whitehorse, YT, Canada), a strong seasonal difference in the $\delta^{18} \mathrm{O}$ values from precipitation exists, with winter precipitation more depleted in ${ }^{18} \mathrm{O}$ than summer precipitation by up to $10 \%$. This

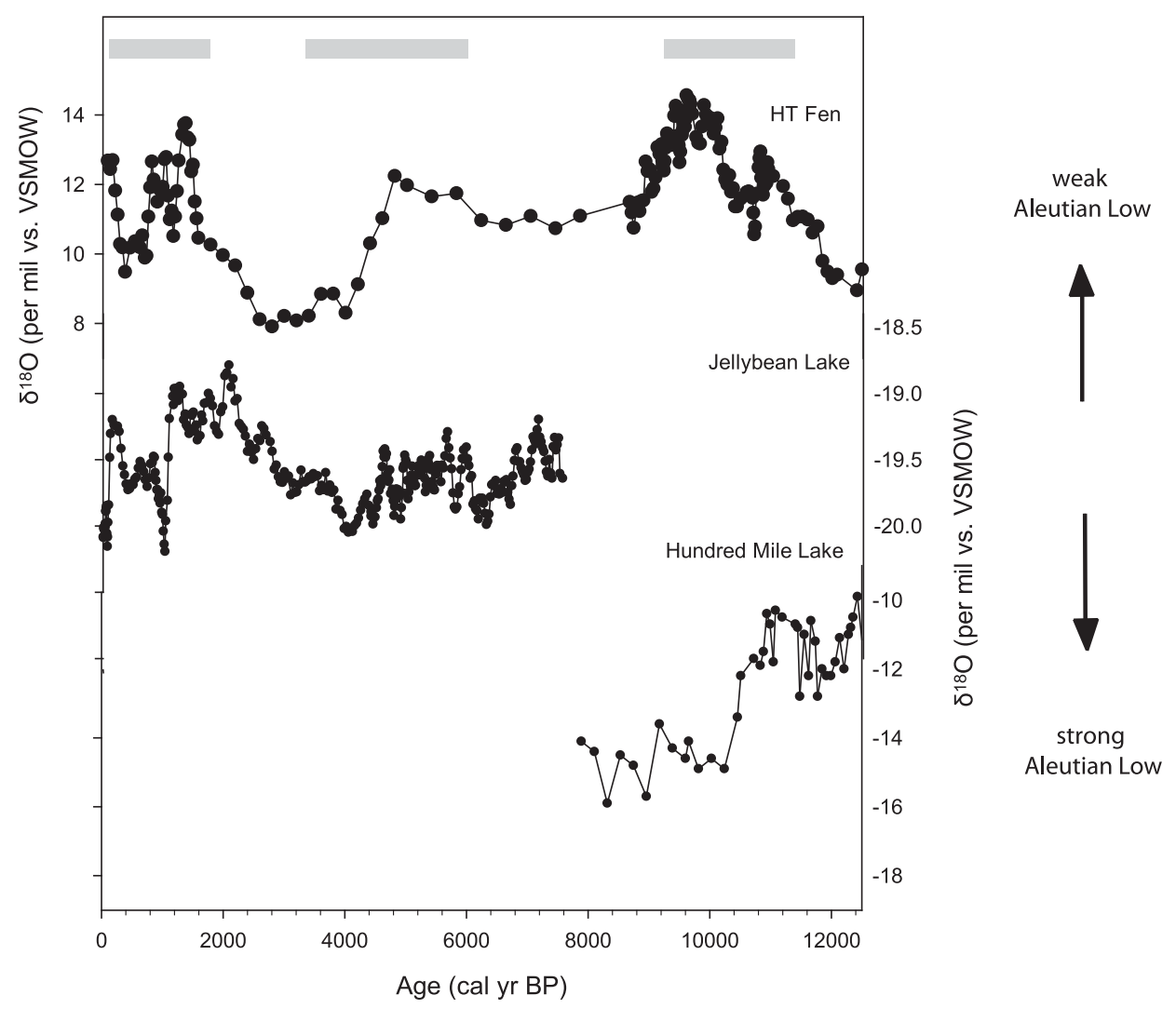

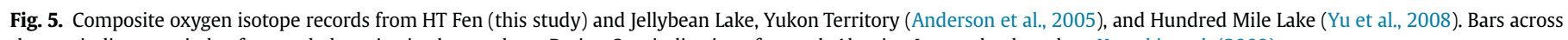
the top indicate periods of expanded sea ice in the southern Bering Sea, indicative of a weak Aleutian Low today based on Katsuki et al. (2009). 
indicates that the early Holocene climate may have been more strongly influenced by summer precipitation than winter precipitation, while the mid-Holocene was largely influenced by a strong AL. Unlike lakes, however, the water uptake in peatlands is largely driven by summertime biological activity, suggesting that if the AL, predominantly a wintertime phenomenon, is imprinting in the HT Fen peat oxygen isotope fractionation, then the winter precipitation plays a larger role in influencing the peatland water year-round during a strengthened AL. This could either be through a long residence time of water from snowmelt on the peatland surface, or a rapid recharge of the groundwater from snowmelt. Either way, if our interpretation of a strengthened AL associated with lighter $\delta^{18} \mathrm{O}$ is correct, it suggests that the plants do take up water from winter snowmelt for at least part of the growing season, but that it is not sufficient to fuel high moss productivity, as accumulation rates during an inferred strengthened AL periods are low.

Although numerous AK lake records suggest dry conditions during the early Holocene (Anderson et al., 2006; Kaufman et al., 2010), our peat records show rapid accumulation of wellpreserved peat, which suggests conditions were not dry enough to hamper peat accumulation (Jones et al., 2009; Jones and Yu, 2010; this record). This may suggest that the timing of precipitation and the recharge of water levels in lakes versus peatlands may differ on the Kenai Lowlands. However, given the presence of more aquatic macrofossils in the studied Kenai Lowland lakes during the early Holocene, followed by an increase in bryophytes during the mid-Holocene (Anderson et al., 2006) may actually suggest relatively wet conditions during the early Holocene followed by lake drying during the mid-Holocene. Additionally, an overall decrease in charcoal in the early Holocene until 10,700 cal yr BP further suggests wetter conditions. High peat accumulation during an inferred weak AL during the early Holocene suggests that summer precipitation was higher during those periods and that winter precipitation (a stronger $\mathrm{AL}$ ) is relatively unimportant for peatland development (and may actually help promote winter decomposition under a deep snowpack (e.g. Sturm et al., 2001)). The high insolation seasonality has been suggested as a mechanism for promoting peatland expansion and peat accumulation, where warm, long summers promoted high rates of productivity and cold, dry winters helped reduce winter respiration (Jones and Yu, 2010).

In order to achieve warm/wet conditions in the summer in this portion of Alaska, atmospheric high pressure ridging over Alaska and troughing farther west than normal would need to occur (Edwards et al., 2001). While this is a rare scenario under modern climate, it is possible that this type of pattern persisted during the early Holocene, with more frequent storm tracks originating from the east Siberian Sea associated with an intensified Pacific subtropical high. Just as vegetation communities in Alaska during the early Holocene have no modern analogue (Edwards et al., 2005), the climate itself may have had no modern analogue. Early Holocene summer insolation was 6\% higher than today (Berger and Loutre, 1991) and the opening of the Bering Strait (Hopkins, 1959; Keigwin et al., 2006) and remnant ice sheet effects to the east (Kaufman et al., 2004), in addition to changing sea ice regimes in the Bering Sea and rising sea level, likely caused a significant climatic reorganization during the early Holocene. Although peatlands were expanding at a rapid rate across Alaska during the HTM (Jones and Yu, 2010), evidence for low early Holocene precipitation exists from peat records to the east (Heusser et al., 1985), where both pollen transfer functions and slow accumulation of humified peat suggest both a weak Aleutian Low and a summer precipitation deficit during the early Holocene (Heusser et al., 1985). On the other hand, Katsuki et al. (2009) report greater-than-present sea ice in the Bering Sea during the early Holocene, consistent with a weaker $\mathrm{AL}$ and the formation of a secondary low pressure system that delivered moisture to the southern Alaska coast. Decreasing sea ice and a strengthened AL occur after 9800 cal yr BP, consistent with the pollen record from Grandfather Lake in southwestern Alaska (Hu et al., 1995), both of which are generally consistent with the shift toward lighter isotopes in the HT Fen record. The HundredMile Lake record from the Matanuska Valley shows a large isotopic shift to lighter values around 10,500 cal yr BP, slightly earlier than this record, but consistent in direction and in interpretation to an increase in winter precipitation following the early Holocene (Yu et al., 2008). This suggests that precipitation in this region is not only complicated by orographic effects but may also be controlled by a site's location relative to the Bering Sea.

The shift to a $6 \%$ lower $\delta^{18} \mathrm{O}$ value (relative to the early Holocene peak) after the HTM persists from $\sim 5000$ to 1800 cal yr BP, coincident with decreased peat preservation, increased charcoal, and overall lower $C$ accumulation rates across the Kenai Peninsula (Figs. 2 and 4). The potential for a hiatus and/or extremely low accumulation causes us to caution against over-interpreting this portion of the record, particularly the timing of shifts during this interval. However, the oxygen isotopic shifts are consistent with a strengthened $\mathrm{AL}$ and a cooler climate related to Neoglaciation, when mountain glaciers expanded (Barclay et al., 2009), either as the result of cooler temperatures or increased precipitation. Drier conditions in the Kenai Lowlands during this time appear to be consistent with a stronger AL, which would deliver more winter precipitation to the Kenai Mountains, and increase isotopic fractionation for any precipitation reaching the Kenai Lowlands. This winter precipitation signature is incorporated into the peatland plants in the summer as the snow melts in the spring and plants begin photosynthesizing, although the majority of the water is useless to the plants, ultimately resulting in the observed low accumulation rates. The interpretation of increased winter precipitation during this time period is consistent with the observed difference in $\delta^{18} \mathrm{O}$ values between winter and summer air masses in Alaska (Global Network of Isotopes in Precipitation (GNIP) database (http://www-naweb.iaea.org/napc/ih/IHS_resources_ gnip.html); Yu et al., 2008) and sea ice records from the Bering Sea, which show a stronger-than-present AL from 40003000 cal yr BP (Katsuki et al., 2009). These results are also consistent, again, with the Jellybean Lake record (Anderson et al., 2005) and the Marcella Lake record (Anderson et al., 2007) from the southern Yukon Territory, which are both located on the leeward side of the Wrangell-St. Elias Mountains and would produce similar precipitation patterns as the Kenai Lowlands with a strengthened, more easterly AL (Anderson et al., 2005, 2007). Isotopically, the Kenai Lowlands received a greater fraction of winter precipitation compared to summer precipitation during this period. Lower summer precipitation and cooler conditions reduce overall NPP, while the water source of any peat productivity during this interval is derived from precipitation that fell during the winter. Thus, under low summer precipitation, the available water is delivered to the peatland following spring snowmelt, which may not last through the growing season. These combined factors would have decreased plant productivity on the peatland and increased decomposition. The abundant charcoal provides further evidence for dry conditions on the Kenai Lowlands between 5000 and $1800 \mathrm{cal} \mathrm{yr} \mathrm{BP,} \mathrm{and} \mathrm{overall} \mathrm{cooler} \mathrm{temperatures}$ during this period also raises the possibility that permafrost aggraded, causing drier surface conditions and decreasing belowground carbon storage. While the Kenai Peninsula peatlands show drier conditions during this mid-Holocene period, Interior lake levels increased (Abbott et al., 2000; Barber and Finney, 2000), suggesting that the coastal versus Interior precipitation patterns differed, which could be attributed to changes in circulation patterns that would deliver moisture to the south-central coast but 
not the Interior and vice versa, patterns consistent with modern and paleoclimate anomalies across Beringia (Edwards et al., 2001).

A relative increase in $\delta^{18} \mathrm{O}$ values from 1500 to $615 \mathrm{cal} \mathrm{yr} \mathrm{BP}$ is roughly consistent with, albeit slightly more persistent than, an increase in average annual air temperatures across the northern hemisphere ( 1100-700 cal yr BP) (Osborn and Briffa, 2006) and in Alaska, as evidenced by lake proxy records (Hu et al., 2001; Loso, 2009) and tree growth and retreated glacial margins (D'Arrigo et al., 2006; Wiles et al., 2008). This evidence once again suggests a period of a weaker and/or more westward AL and a greater predominance of summer precipitation. Increased peat accumulation (Fig 2) and a return of peatland bryophytes (Fig 3) suggests greater moisture delivery to the Kenai Lowland peatlands, either through enhanced summer precipitation or higher water tables from increased glacial meltwater, or some combination of the two.

The final $2-5 \%$ decrease in $\delta^{18} \mathrm{O}$ values that occurs from 600 to 150 cal yr BP similar to the timing of the LIA on the Kenai Peninsula (Wiles and Calkin, 1994), which has been documented from lake records (Anderson et al., 2007; Loso, 2009; Clegg and Hu, 2010; Chipman et al., 2012) and glacial advances (Wiles and Calkin, 1994; Wiles et al., 2008; Barclay et al., 2009) in the Kenai Mountains. The HT Fen oxygen isotope record suggests cooler temperatures and a greater contribution from winter versus summer precipitation. This pattern is broadly consistent across Alaska, as shown by a similar decrease in $\delta^{18} \mathrm{O}$ values from Jellybean Lake, Yukon Territory (Anderson et al., 2005) and Takahula Lake, Brooks Range, Alaska (Clegg and Hu, 2010). While a general consensus exists that summer temperatures were cooler during the LIA (Wiles et al., 2008; Barclay et al., 2009; Daigle and Kaufman, 2009; Loso, 2009), some disagreement remains as to whether the AL was stronger (Wiles and Calkin, 1994; D'Arrigo et al., 2005) or weaker (Daigle and Kaufman, 2009; Gonyo et al., 2012). In keeping with the interpretation for the rest of the HT Fen record, the lighter $\delta^{18} \mathrm{O}$ values from 600 to $150 \mathrm{cal}$ yr BP suggest a stronger AL, while a change to heavier $\delta^{18} \mathrm{O}$ values in the last 200 years of the record is consistent with interpretations from other studies that the $\mathrm{AL}$ weakened in the 19th Century AD (Anderson et al., 2005; Rupper et al., 2005; Daigle and Kaufman, 2009).

\section{Conclusions}

The $\delta^{18} \mathrm{O}_{\text {TOM }}$ values and plant macrofossil evidence from the HT Fen on the Kenai Lowlands, Alaska provides a long-term record of moisture variability since deglaciation. Warmer intervals such as the Bølling-Allerød, Holocene Thermal Maximum, and Medieval Climate Anomaly are associated with a relatively higher $\delta^{18} \mathrm{O}_{\mathrm{TOM}}$ signature, while cooler intervals such as the YD, mid-Holocene, and LIA are associated with a relatively lower $\delta^{18} \mathrm{O}_{\mathrm{TOM}}$ signature. These patterns suggest that not only does temperature play a role in the observed variation in $\delta^{18} \mathrm{O}$ values, but also that the strength and position of the $\mathrm{AL}$ and variation in the relative proportional contribution of summer and winter precipitation are important in controlling $\delta^{18} \mathrm{O}$ values in this peat record through time. Periods of isotopic enrichment are consistent with an inferred increase in the strength of the AL in south-central Alaska, while periods of isotopic depletion are associated with a decrease in winter precipitation (driven by the AL). These periods of greater summer versus winter precipitation are also associated with an increase in peat accumulation rates and peatland expansion, suggesting that winter precipitation hinders peat accumulation, while greater summer moisture enhances peat accumulation. Further research is needed to test these hypotheses, including collection of modern water samples throughout the year to track precipitation sources on the Kenai Lowlands to better understand how changes in source water are reflected in the peatland plants.

\section{Acknowledgments}

This project was funded by a Columbia University LDEO Climate Center grant, NASA/GISS, and a grant from the National Science Foundation (Award \#ARC-1022979). Matthew Wooller was supported by a grant from the National Science Foundation (Award \#ARC-1204233).

We thank Ed Berg, Toby Burke, and Matt Bowser of the Kenai National Wildlife Refuge for field assistance. Norton Miller aided with moss identification. Thanks to Lesleigh Anderson and Jason Addison of the USGS and one anonymous reviewer for providing helpful comments that improved the manuscript. Any use of trade, product or firm names is for descriptive purposes only and does not imply endorsement by the U.S. government.

\section{References}

Abbott, M.B., Finney, B.P., Edwards, M.E., Kelts, K.R., 2000. Lake-level reconstructions and paleohydrology of Birch Lake, Central Alaska, based on seismic reflection profiles and core transects. Quat. Res. 53, 154-166.

Abbott, M.B., Edwards, M.E., Finney, B.P., 2010. A 40,000-yr record of environmental change from Burial Lake in Northwest Alaska. Quat. Res. 1, 156-165.

Anderson, L., Abbott, M.B., Finney, B.P., Burns, S.J., 2005. Regional atmospheric circulation change in the North Pacific during the Holocene inferred from lacustrine carbonate oxygen isotopes, Yukon Territory, Canada. Quat. Res. 64, 21-35.

Anderson, R.S., Hallett, D.J., Berg, E., Jass, R.B., Toney, J.L., De Fontaine, C.S. DeVolder, A., 2006. Holocene development of boreal forests and fire regimes on the Kenai Lowlands of Alaska. Holocene 16, 791-803.

Anderson, L., Abbott, M.B., Finney, B.P., Burns, S.J., 2007. Late Holocene moisture balance variability in the southwest Yukon Territory, Canada. Quat. Sci. Rev. 26, 130-141.

Barber, V.A., Finney, B.P., 2000. Late Quaternary paleoclimatic reconstructions for interior Alaska based on paleolake-level data and hydrologic models. J. Paleolimnol. 24 (1), 29-41.

Barclay, D.J., Wiles, G.C., Calkin, P.E., 2009. Holocene glacier fluctuations in Alaska. Quat. Sci. Rev. 28 (21), 2034-2048.

Berger, A., Loutre, M.F., 1991. Insolation values for the climate of the last 10 million years. Quat. Sci. Rev. 10 (4), 297-317.

Birks, H.H., 2000. Aquatic macrophyte vegetation development in Kråkenes Lake, western Norway, during the late-glacial and early-Holocene. J. Paleolimnol. 23 (1), 7-19.

Bodner, M., 1994. Inorganic carbon source for photosynthesis in the aquatic macrophytes Potamogeton natans and Ranunculus fluitans. Aquat. Bot. 48 (2), 109-120.

Borella, S., Leuenberger, M., Saurer, M., 1999. Analysis of delta O-18 in tree rings: wood-cellose comparison and method dependent. J. Geophys. Res. 104, 1926719273. http://dx.doi.org/10.1029/1999JD900298.

Brenninkmeijer, C.A.M., van Geel, B., Mook, W.G., 1982. Variations in the D/H and ${ }^{18} \mathrm{O} /{ }^{16} \mathrm{O}$ ratios in cellulose extracted from a peat core. Earth Planet. Sci. Lett. 61, 283-290.

Calkin, P.E., Wiles, G.C., Barclay, D.J., 2001. Holocene coastal glaciation of Alaska. Quat. Sci. Rev. 20 (1), 449-461.

Chipman, M.L., Clegg, B.F., Hu, F.S., 2012. Variation in the moisture regime of northeastern interior Alaska and possible linkages to the Aleutian Low: inferences from a late-Holocene $\delta^{18} \mathrm{O}$ record. J. Paleolimnol. 48 (1), 69-81.

Clegg, B.F., Hu, F.S., 2010. An oxygen-isotope record of Holocene climate change in the south-central Brooks Range, Alaska. Quat. Sci. Rev. 29, 928-939.

Clymo, R.S., Turunen, J., Tolonen, K., 1998. Carbon accumulation in peatland. Oikos, 368-388.

Crum, H.A., Anderson, L.E., 1981. Mosses of Eastern North America, vols. 1 and 2. Columbia University Press, New York.

Cullen, L.E., Grierson, P.F., 2006. Is cellulose extraction necessary for developing stable carbon and oxygen isotopes chronologies from Callitris glaucophylla? Palaeogeogr. Palaeoclimatol. Palaeoecol. 236, 206-216.

Daigle, T.A., Kaufman, D.S., 2009. Holocene climate inferred from glacier extent, lake sediment and tree rings at Goat Lake, Kenai Mountains, Alaska, USA. J. Quat. Sci. 24, 33-45.

Dansgaard, W., 1964. Stable isotopes in precipitation. Tellus 16, 436-468.

D’Arrigo, R., Wilson, R., Deser, C., Wiles, G., Cook, E., Villalba, R., Tudhope, Al., Cole, J., Linsley, B., 2005. Tropical-north Pacific climate linkages over the past four centuries. J. Clim. 18, 5253-5265.

D’Arrigo, R., Wilson, R., Jacoby, G., 2006. On the long-term context for late twentieth century warming. J. Geophys. Res. 111 (D3), D03103.

Dean, W.E., 1974. Determination of carbonate and organic matter in calcareous sediments and sedimentary rocks by loss-on-ignition: comparison with other methods. J. Sed. Petrol. 44, 242-248.

de Fontaine, C.S., Kaufman, D.S., Scott Anderson, R., Werner, A., Waythomas, C.F., Brown, T.A., 2007. Late Quaternary distal tephra-fall deposits in lacustrine sediments, Kenai Peninsula, Alaska. Quat. Res. 68 (1), 64-78.

Deniro, M.J., Epstein, S., 1979. Relationship between the oxygen isotope ratios of terrestrial plant cellulose, carbon dioxide, and water. Science 204, 51-53. 
Edwards, M.E., Mock, C.J., Finney, B.P., Barber, V.A., Bartlein, P.J., 2001. Potentia analogues for paleoclimatic variations in eastern interior Alaska during the past 14,000 yr: atmospheric-circulation controls of regional temperature and moisture responses. Quat. Sci. Rev. 20, 189-202.

Edwards, M.E., Brubaker, L.B., Lozhkin, A.V., Anderson, P.M., 2005. Structurally nove biomes: a response to past warming in Beringia. Ecology 86 (7), 1696-1703.

Engstrom, D.R., Hansen, B.C.S., Wright Jr., H.E., 1990. A possible Younger Dryas record in southeastern Alaska. Science 250, 1383-1385.

Fisher, D.A., Wake, C., Kreutz, K., Yalcin, K., Steig, E., Mayewski, P., Burns, S.J., 2004. Stable isotope records from Mount Logan, Eclipse ice cores and nearby Jellybean Lake. Water cycle of the North Pacific over 2000 years and over five vertical kilometres: sudden shifts and tropical connections. Géograph. Phys. Quat. 58, 337-352.

Gignac, L.D., Vitt, D.H., Zoltai, S.C., Bayley, S.E., 1991. Bryophyte response surfaces along climatic, chemical, and physical gradients in peatlands of western Canada. Nova Hedwigia 53 (1-2), 27-71.

Gonyo, A.W., Yu, Z., Bebout, G.E., 2012. Late Holocene change in climate and atmospheric circulation inferred from geochemical records at Kepler Lake, southcentral Alaska. J. Paleolimnol. 48, 55-67.

Heusser, C.J., Heusser, L.E., Peteet, D.M., 1985. Late-Quaternary climatic change on the American North Pacific Coast. Nature 315, 485-487.

Hopkins, D.M., 1959. Cenozoic history of the Bering Land Bridge the seaway between the Pacific and Arctic basins has often been a land route between Siberia and Alaska. Science 129 (3362), 1519-1528.

Hu, F.S., Ito, E., Brown, T.A., Curry, B.B., Engstrom, D.R., 2001. Pronounced climatic variations in Alaska during the last two millennia. Proc. Natl. Acad. Sci. U. S. A. 98, 10552-10556.

Hu, F.S., Brubaker, L.B., Anderson, P.M., 1995. Postglacial vegetation and climatechange in the northern Bristol Bay region, southwestern Alaska. Quat. Res 43, 382-392.

Hunt, S., Yu, Z., Jones, M., 2013. Lateglacial and Holocene climate, disturbance and permafrost peatland dynamics on the Seward Peninsula, western Alaska. Quat. Sci. Rev. 63, 42-58.

IAEA/WMO, 2001. Global Network for Isotopes in Precipitation. In: The GNIP Database. Accessible at: http://isohis.iaea.org.

Janssens, J.A., 1983. A quantitative method for stratigraphic analysis of bryophytes in Holocene peat. J. Ecol. 71, 189-196.

Janssens, J.A., 1990. Ecology of Peatland Bryophytes and Paleoenvironmental Reconstruction of Peatlands Using Fossil Bryophytes. University of Minn. Lab Manual, pp. 1-71.

Jones, M.C., 2008. Climate and Vegetation History from Late-glacial and Holocene Peat from the Kenai Peninsula, Alaska: a Record of Pollen, Macrofossils, Stable Isotopes, and Carbon Storage (Ph.D. thesis). Columbia University, New York, NY.

Jones, M.C., Peteet, D.M., Kurdyla, D., Guilderson, T., 2009. Climate and vegetation history from a 14,000-year peatland record, Kenai Peninsula, Alaska. Quat. Res. 72, 207-217. http://dx.doi.org/10.1016/j.yqres.2009.04.002.

Jones, M.C., Yu, Z., 2010. High sensitivity of Alaskan peatlands to temperature seasonality during the Holocene thermal maximum. Proc. Natl. Acad. Sci. U. S. A 107, $7347-7352$

Kaislahti Tillman, P., Holzkämper, S., Kuhry, P., Sannel, A.B.K., Loader, N.J., Robertson, I., 2010. Stable carbon and oxygen isotopes in Sphagnum fuscum peat from subarctic Canada: implications for paleoclimate studies. Chem. Geol. 270, 216-226.

Katsuki, K., Khim, Boo-Keun, Itaki, T., Harada, N., Sakai, H., Ikeda, T., Takahashi, K. Yusuki, O. Asahi, H, 2009. Land-sea linkage of Holocene paleoclimate on the Southern Bering Continental Shelf. Holocene 19, 747-756.

Kaufman, D.S., Ager, T.A., Anderson, N.J., Anderson, P.M., Andrews, J.T., Bartlein, P.J., Brubaker, L.B., Coats, L.L., Cwynar, L.C., Duvall, M.L., Dyke, A.S., Edwards, E., Eisner, W.R., Gajewski, K., Geirsdöttir, A., Hu, F.S., Jennings, A.E., Kaplan, M.R. Kerwin, M.W., Lozhkin, A.V., MacDonald, G.M., Miller, G.H., Mock, C.J., Oswald, W.W., Otto-Bliesner, B.L., Porinchu, D.F., Ruhland, K., Smol, J.P. Steig, E.J., Wolfe, B.B., 2004. Holocene thermal maximum in the western Arctic (0-180 W). Quat. Sci. Rev. 23, 529-560.

Kaufman, D.S., Scott Anderson, R., Hu, F.S., Berg, E., Werner, A., 2010. Evidence for a variable and wet Younger Dryas in southern Alaska. Quat. Sci. Rev. 29, 1445-1452.

Keigwin, L.D., Donnelly, J.P., Cook, M.S., Driscoll, N.W., Brigham-Grette, J., 2006. Rapid sea-level rise and Holocene climate in the Chukchi Sea. Geology 34 (10), 861-864.

Leng, M.J., Marshall, J.D., 2004. Palaeoclimate interpretation of stable isotope data from lake sediment archives. Quat. Sci. Rev. 23 (7), 811-831.

Loader, N.J., McCarroll, D., Van der Knaap, W.O., Robertson, I., Gagen, M., 2007. Characterizing carbon isotopic variability in Sphagnum. Holocene 17, 403-410.

Loso, M.G., 2009. Summer temperatures during the Medieval Warm Period and Little Ice Age inferred from varved proglacial lake sediments in southern Alaska. J. Paleolimnol. 41 (1), 117-128.

Lynch, J.A., Clark, J.S., Bigelow, N.H., Edwards, M.E., Finney, B.P., 2003. Geographic and temporal variations in fire history in boreal ecosystems of Alaska. J. Geophys. Res. 108 (D1). FFR8-1.

Mantua, N.J., Hare, S.R., Zhang, Y., Wallace, J.M., Francis, R.C., 1997. A Pacific interdecadal climate oscillation with impacts on salmon production. Bull. Am. Meteorol. Soc. 78 (6), 1069-1079.

Mann, D.H., Crowell, A.L., Hamilton, T.D., Finney, B.P., 1998. Holocene geologic and climatic history around the Gulf of Alaska. Arct. Anthropol. 35 (1), 112-131.

Mann, D.H., Peteet, D.M., Reanier, R.E., Kunz, M.L., 2002. Responses of an arctic landscape to Lateglacial and early Holocene climate changes: the importance of moisture. Quat. Sci. Rev. 21, 997-1021.
Ménot, G., Burns, S.J., 2001. Carbon isotopes in ombrogenic peat bog plants as climatic indicators: calibration from an altitudinal transect in Switzerland. Org. Geochem 32, 233-245.

Ménot-Combes, G., Burns, S.J., Leuenberger, M., 2002. Variations of ${ }^{18} \mathrm{O} /{ }^{16} \mathrm{O}$ in plants from temperate peat bogs (Switzerland): implications for paleoclimatic studies. Earth Planet. Sci. Lett. 202, 419-434.

Mock, C.J., Bartlein, P.J., Anderson, P.M., 1998. Atmospheric circulation patterns and spatial climatic variation in Beringia. Int. J. Climatol. 10, 1085-1104.

Monacci, N.M., Meier-Grünhagen, U., Finney, B.P., Behling, H., Wooller, M.J., 2009. Mangrove ecosystem changes during the Holocene at Spanish Lookout Cay, Belize. Palaeogeogr. Palaeoclimatol. Palaeoecol. 280, 37-46.

Moritz, R.E., Bitz, C.M., Steig, E.J., 2002. Dynamics of recent climate change in the Arctic. Science 297, 1497-1501.

Moschen, R., Kühl, N., Rehberger, I., Lücke, A., 2009. Stable carbon and oxygen isotopes in sub-fossil Sphagnum: assessment of their applicability for palaeoclimatology. Chem. Geol. 259 (3-4), 262-272.

Osborn, T.J., Briffa, K.R., 2006. The spatial extent of 20th-century warmth in the context of the past 1200 years. Science 311 (5762), 841-844.

Overland, J.E., Miletta, J.M., Bond, N.A., 1999. Decadal variability of the Aleutian Low and its relation to high-latitude circulation. J. Clim. 12, 1542-1549.

Peteet, D.M., 1986. Modern pollen rain and vegetational history of the Malaspina Glacier District, Alaska. Quat. Res. 25 (1), 100-120.

Peteet, D.M., Mann, D.H., 1994. Late-glacial vegetational, tephra, and climatic history of southwestern Kodiak Island, Alaska. Ecoscience 1, 255-267.

Reger, R.D., Pinney, D.S., 1997. Last major glaciation of Kenai Lowland. In: Karl, S.M. Vaughn, N.R., Ryherd, T.J. (Eds.), Guide to the Geology of the Kenai Peninsula, Alaska. Alaska Geological Society, Anchorage, pp. 54-66.

Reger, R.D., Sturmann, A.G., Berg, E.E., Burns, P.A.C., 2007. Guidebook 8. A Guide to the Late Quaternary History of the Northern and Western Kenai Peninsula, Alaska. State of Alaska Department of Natural Resources and Division of Geological and Geophysical Surveys, Alaska.

Reimer, P.J., Baillie, M.G., Bard, E., Bayliss, A., Beck, J.W., Blackwell, P.G., Bronk Ramsey, C., Buck, C.E., Burr, G.S., Edwards, R.L., Friedrich, M., Grootes, P.M., Guilderson, T.P., Hajdas, I., Heaton, T.J., Hogg, A.G., Hughen, K.A., Kaiser, K.F. Kromer, B., McCormac, F.G., Manning, S.W., Reimer, Ron W., Richards, D.A. Southon, J.R. Talamo, S., Turney, C.S.M., van der Plicht, J., Weyhenmeyer, C.E. 2009. IntCal09 and Marine09 radiocarbon age calibration curves, 0-50,000 years cal BP. Radiocarbon 51, 1111-1150.

Rupper, S., Steig, E.J., Roe, G., 2005. The relationship between snow accumulation at Mt. Logan, Yukon, Canada, and climate variability in the North Pacific. J. Clim. 17 4724-4739.

Rymer, M.J., Sims, J.D., 1982. Lake-sediment evidence for the date of deglaciation of the Hidden Lake area, Kenai Peninsula, Alaska. Geology 10, 314-316.

Schiff, C.J., Kaufman, D.S., Wolfe, A.P., Dodd, J., Sharp, Z., 2009. Late Holocene stormtrajectory changes inferred from the oxygen isotope composition of lake diatoms, south Alaska. J. Paleolimnol. 41, 189-208.

Skrzypek, G., Kaluzny, A., Jedrysek, M.O., 2007. Carbon stable isotope analyses of mosses - comparisons of bulk organic matter and extracted nitrocellulose. Am. Soc. Mass Spectrom. 18, 1453-1458.

Sturm, M., Holmgren, J., McFadden, J.P., Liston, G.E., Chapin III, F.S., Racine, C.H. 2001. Snow-shrub interactions in Arctic tundra: a hypothesis with climatic implications. J. Clim. 14 (3), 336-344.

Trenberth, K.E., Hurrell, J.W., 1994. Decadal atmospheric-ocean variations in the Pacific. Clim. Dyn. 9, 303-319.

Watts, W.A., Winter, T.C., 1966. Plant macrofossils from Kirchner Marsh, Minnesota; a paleoecological study. Geol. Soc. Am. Bull. 77, 1339-1359.

Wiles, G.C., Calkin, P.E., 1994. Late Holocene, high-resolution glacial chronologies and climate, Kenai Mountains, Alaska. Geol. Soc. Am. Bull. 106, 281-303.

Wiles, G.C., Barclay, D.J., Calkin, P.E., Lowell, T.V., 2008. Century to millennial-scale temperature variations for the last two thousand years indicated from glacial geologic records of Southern Alaska. Glob. Planet. Change 60 (1), 115-125.

Wolfe, B.B., Edwards, T.W.D., Elgood, R.J., Beuning, K.R.M., 2001. Carbon and oxygen isotope analysis of lake sediment cellulose: methods and applications. In: Last, W.M., Smol, J.P. (Eds.), Tracking Environmental Change Using Lake Sediments, Physical and Geochemical Methods, vol. 2. Kluwer Publishers, Dordrecht, The Netherlands, pp. 373-400.

Wooller, M.J., Morgan, R., Fowell, S.J., Behling, H., Fogel, M., 2007a. A multi-proxy peat record of Holocene mangrove paleoecology from Twin Cays, Belize. Holocene 17 (8), 1129-1139.

Wooller, M.J., Axford, Y., Wang, Y., 2007b. A multiple stable isotope record of Late Quaternary limnological changes and chironomid paleoecology from north eastern Iceland. J. Paleolimnol. 40, 63-77.

Yu, Z., Vitt, D.H., Campbell, I.D., Apps, M.J., 2003. Understanding Holocene peat accumulation pattern of continental fens in western Canada. Can. J. Bot. 81 267-282.

Yu, Z., Walker, K.N., Evenson, E.B., Hajdas, I., 2008. Lateglacial and early Holocene climate oscillations in the Matanuska Valley, south-central Alaska. Quat. Sci. Rev. 27, 148-161.

Yu, Z., Beilman, D.W., Jones, M.C., 2009. Sensitivity of Northern Peatland carbon dynamics to Holocene climate change. In: Baird, Andrew J., Belyea, Lisa R. Comas Xavier, Reeve A.S., Slater, Lee D. (Eds.), Carbon Cycling in Northern Peatlands AGU Monograph Series 184, pp. 55-69.

Zanazzi, A., Mora, G., 2005. Paleoclimatic implications of the relationship between oxygen isotope ratios of moss cellulose and source water in wetlands of Lake Superior. Chem. Geol. 222 (3), 281-291. 